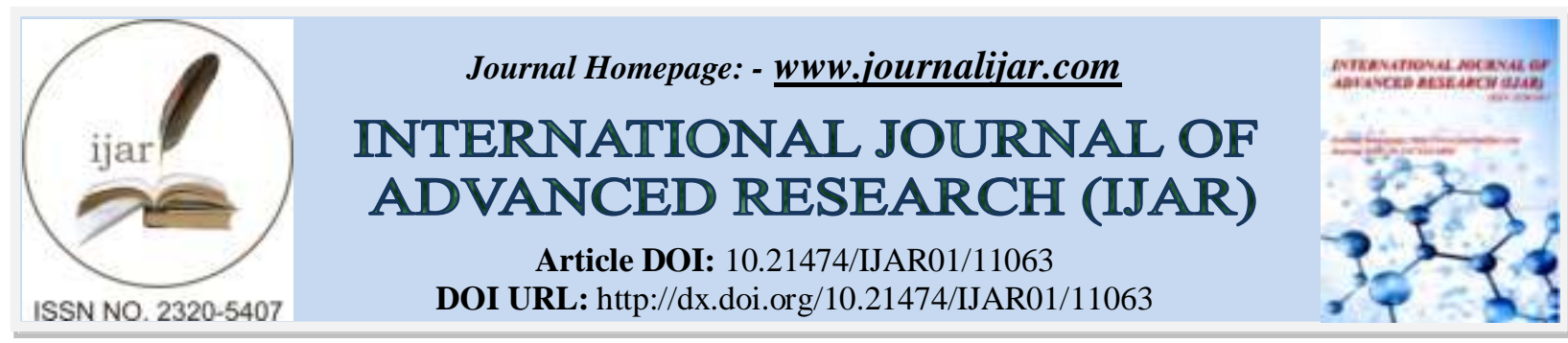

RESEARCH ARTICLE

\title{
ANTIMICROBIAL PROPERTIES OF SEVERAL TYPES OF ENDODONTIC SEALERS; A SYSTEMATIC REVIEW
}

\section{Dr. Mohsen Daghustani ${ }^{1}$, Dr. Muhannad Mohammed Suhail ${ }^{2}$, Dr. Mohammed Mahmoud Abed ${ }^{2}$, Dr. Rakan Ibrahim Alrubaish ${ }^{2}$, Dr. Khalid Suliman Alatni ${ }^{2}$, Dr. Haidar Jawad Alkhalifah ${ }^{2}$ and Dr. Waddah Abdullah Alabdaly ${ }^{3}$}

1. Consultant Endodontist, Member of the Scientific Council, Saudi Board of Endodontics, Swedish Board in Endodontics, Fellowship in Endodontic Microsurgery, Jeddah Specialty Dental Centre, Ministry of Health.

2. Dental Intern, Riyadh Elm University, KSA.

3. Dental Intern, Imam Abdulrahman University, KSA.

\section{Manuscript Info}

Manuscript History

Received: 01 April 2020

Final Accepted: 05 May 2020

Published: June 2020

\section{Abstract}

Copy Right, IJAR, 2020,. All rights reserved.

\section{Introduction:-}

Endodontic treatment is a necessary procedure in the restoration of teeth integrity, function, and morphology by significantly reducing or eliminating the bacteria present in the root canal, which can cause infection. After endodontic treatment, there is still a high chance of the teeth developing periapical lesions and pulpal illnesses due to the microorganisms that remain in the root canal or dentin tubules, as well as their products (Munitić, Peričić, Utrobičić, Bago, and Puljak 2019, p. 2).In specific conditions like unsuitable aseptic situations, the microorganisms in the oral cavity can cause infection by penetrating to the canal of the root duringthetreatment procedure (Gholamhoseini, Alizadeh, and Bolbolian2018, p. 261).Munitić et al. (2019, p. 2) explain that those microorganisms are often organized in biofilms within the root canal, making them more resistant to various kinds of antimicrobials than when in the planktonic state. Some of the most common resistant species include Candida albicans, Staphylococcus aureus, and Enterococcus faecalis (Gholamhoseini et al. 2018, p. 261). Such bacteria often encourage the failure of endodontic treatments, thereby necessitating the use of sealers that fill the canal irregularities and central materialsthatoccupy space.

When an individual is suffering from distinct pulpal diseases, sealers with desirable antimicrobial activities should be selected because of their capability to reduce and avoid the remaining bacteria's growth and development. Therefore, for the treatment of endodontic illnesses to be successful, the microbial load must be entirelyeradicated by chemo-mechanical preparation of root canal (Gholamhoseini et al. 2018, p. 261). The primary roles of the sealers are usually to fill voids, form a connectionbetween the wall of the root canal and the filling material's core, and to act as a lubricant during the treatment procedure (Al-Haddad, A., Ab Aziz, C. and Zeti 2016, p. 1).Al-Haddad et al. (2016, p. 1) explain that in most cases, sealers are grouped based on their main chemical components: bioceramicbased, resin, silicone, glass ionomer, calcium hydroxide, and zinc oxide eugenol. These categories suggest that various kinds of sealers with different constituents and bases that offer multiple antimicrobial properties exist (Gholamhoseini et al. 2018, p. 261).Their existence has been aroused the interest of numerous scholars and

Corresponding Author:- Dr. Mohsen Daghustani 
researchers who desire to determine suitable sealers that can be used during endodontic treatment procedures to prevent infections.

Even so, little research has been performed to investigate the antimicrobial properties of these different types of endodontic sealers. Although Al-Haddad et al. (2016, p. 1) claim that sealers of the root canal have been reviewed across several examinations either based on their constituents or collectively, the studies are not extensive enough. Most importantly, specific types of sealers like the ones based on bioceramicshave only been used during endodontic treatments for the past three decades (Al-Haddad et al. 2016, p. 1). Their popularity can be attributed to the improved utilization of bioceramic technology in dentistry and medicine. Nevertheless, an extensive investigation or review of those particular sealers is yet to be undertaken. In this regard, this systematic review focuses on analyzing the antimicrobial properties of not only the bioceramic-based sealers but also of the other types of endodontic sealers.

\section{Materials and Methods:-}

This section is a crucial aspect of systematic reviews (SRs), and itshould conform to the PRISMA guidelines.Selçuk (2019, p. 57)highlights that PRISMA rule, which stands for Preferred Reporting Items for Systematic Reviews and Meta-Analyses, is a 27-item checklist and a four-phase flow chart that defines the process of identifying, screening, and showing the eligibility of the reports to beincorporated into the analysis. This rule can help with organizing SRsin the required formatand surveying the quality of the investigation. As much asDijkers (2017, p. 1) proposes that the PRISMA rule is more of a detailing guide than a quality-assessment system, its significance in SRs cannot be refuted. In this regard, this SR included its PRISMA chart that portrays the different stages of the review, as can be seen in figure 1 below.
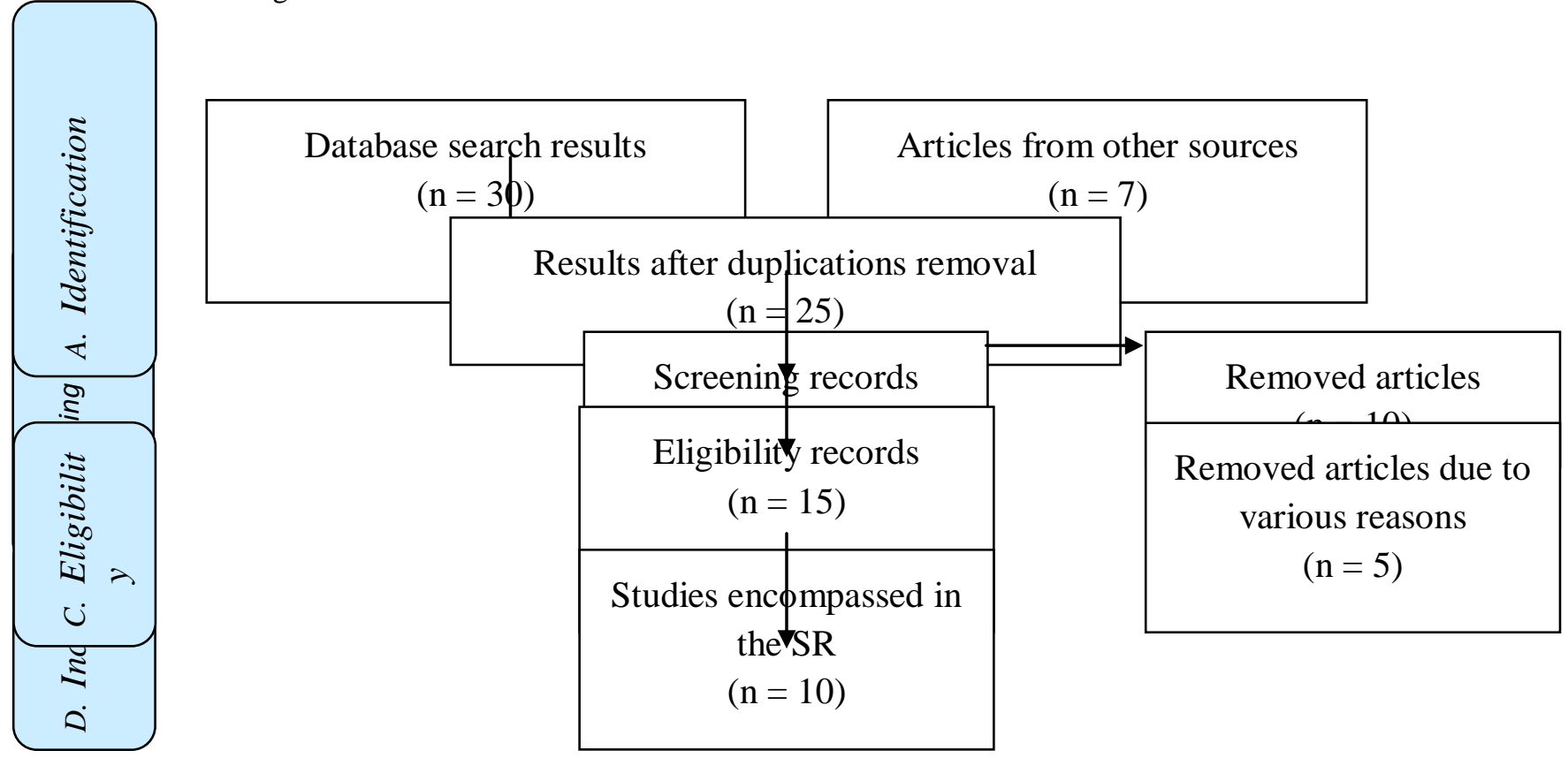

Figure 1:- The PRISMA flow mapdisplaying the different SR stages.

\section{Registration and Protocol}

In most cases, undertaking and registering the SR's protocol is often the regular and desirable occurrence. A significant number of scholars and researchers who perform SRsoftenregister the stepwise procedures they employed in their reviews into various databases. Registering the protocols of SRs ensures that the reportis accurately orchestrated and explicitly chronicled before the survey starts. Consequently, it propels unwavering quality in conduct for the analysis group and supports the obligation, dependability, and straightforwardness of the ultimatelyfinished SR (Jahan, Naveed, Zeshan, and Tahir 2016, p. 4). This statement makes registering of SR protocols vital. 
As already mentioned, numerous databases exist that can be utilized to register protocols. For instance, Jahan et al. (2016, p. 4) outline that the Cochrane Database of Systematic Reviews and PROSPERO stand apart as well known databases utilized for enrolling examination questions and methodology, and they search for previous existing duplicate investigation procedures and inquiries. The PROSPERO is a worldwide database for registering protocols and increasing the transparency of reviews(Page, Shamseer, and Tricco 2018, p. 32). Even so, this review's protocol was not registered. Therefore, it does not have an enlistment number as is consistently the standard in many registered SRs. Regardless, if this protocol is utilized by any invested individuals to undertake a comparable examination, the outcomes will no doubt be the equivalent or fundamentally the same.

\section{Search Strategy}

A distinct strategy was utilized to search for articles and studies that could be incorporated into this SR. Almost all of the publications included in the review usually act as evidence or educational tools to answer the research question or support claims made as part of the investigation topic. In this case, the search strategy was initiated by identifying and determining the databases that could be used to retrieve the studies of interest. The databases that were utilized include Google Scholar, NCBI, PubMed, and EBSCO-host, and they enabled the retrieval of a broad scope of publications and studies that could be used as sources in this SR.

After deciding on the databases, the second step was to categorize and determine the keywords and medical subject headings (MeSHs) that could be used to drive the search and retrieval of the articles already mentioned above. MeSHs are terms assigned to definite articles to portray what theyinvolve(Baumann 2016, p. 171). As for the keywords, they often improve the effectiveness of an article by allowing easy and fast retrieval and recognition of that particular publication. Some of the MeSHs and keywords employed in this SR include sealers, endodontic sealers, antimicrobial sealers, antimicrobial properties, and types of endodontic sealers. They were used to retrieve articles published between $1^{\text {st }}$ January 2016 and $15^{\text {th }}$ March 2020.

\section{Eligibility Criteria}

After the search described above, and the retrieval of various studies, the eligibility criteria were used to select the most suitable articles that could be incorporated into the review. In most cases, the most desirable publications are those that attempt to respond to the investigationinquiry or satisfy the requirement of the inquiry topic. Even so, not all reports with this qualityare usually included in an SR; hence, the use of the eligibility criteria. Pussegoda et al. (2017, p. 131) depict that the eligibility criteria underscore which studies to be used in an SR and the ones to be excluded from the review, thereby necessitating the establishment of an inclusion criterion and exclusion criterion, respectively.In this SR, the inclusion criterion requires that the studies are all published in English, of any design, conducted in any region of the world, and focus on the topic of interest, which is evaluating antimicrobial properties of several types of endodontic sealers. On the same note, the exclusion criterion requires that the articles published in non-English languages and do not concentrate on the topic of interest should be excluded from the review.

\section{Process of Selecting the Studies}

With the help of the eligibility criteria explained above, some of the retrieved articles were selected via a stepwise process and included in the SR.The first step was the random selection of the publications that were retrieved from the databases. The technique was utilized to eliminate or lessen the danger of predisposition that may be experienced suppose a particular rule was utilized to shape or decide the investigations to be retrieved from the databases.After the random selection, the second step encompassed assessing the abstracts and titles of the retrieved articles to define their suitability to be incorporated into the review. This progression empowered the removal of all duplicates. The last step was assessing the reports' full texts to determine whether or not their contents were in line with the SR's topic of interest. The articles that were in line with the research topic were included in the SR while the others with no direct link to the primary concern of the review were excluded. This last step was undertaken in cases where the abstracts and titles of the studies did not give enough data to decide their qualification to be incorporated into the SR.

\section{Extracting Information}

Before any data analysis is done in an SR, information is often extracted from the publication retrieved from the databases and included in the review. Extracting data from the articles included in the SR usually encompasses perusing the examinations and gathering the vital information pertinent to the subject of intrigue. In this SR, extraction of information was performed physically. Those particular articles were read, and explicit data that was considered significant to the subject of intrigue was recovered and recorded in a table. Since the outcomes were not 
by any means the only significant parts of the articles, other data were likewise acquired from the studies. For instance, the names of the authors, years of publications, designs of the studies, and their outcomes were collected from the articles included in the review. The outcomes section highlighted above refers to the results of the studies regarding the antimicrobial properties of several kinds of endodonticsealers.

\section{Analysis of Information}

After the information is extracted from the publications included in the review, it was then analyzed. Ali and Bhaskar (2016, p. 662) explain thatanalyzing the information is a technique that can be utilized to offer importance to the data collected from those particular articles by empowering the identification of vital facts gained from the studies included in the review. Even though several analysis strategies and procedures exist, this SR utilized a table to evaluate the information retrieved from the reports. The table was partitioned into four sections, every one of which was showing specific facts from the publications incorporated into the SR. This procedure empowered examinations of results in the articles to be made, thereby supporting the completion of the outcomes section of this SR.

\section{Risk of Bias Assessment}

When undertaking an SR, the endeavor is inclined continuously to potential predispositions that may affect the outcomes of the review and subsequent conclusions. Predisposition regularly happens if imperfections or limitations in conduct, analysis, or design of an SR distort its results. Therefore, assessing the bias risk involved in conducting an SR is often crucial. Numerous instruments exist that can be utilized to attempt the evaluation referenced. Page, McKenzie, and Higgins (2018, p. 6)highlight that some of those tools can be based on domains, checklists, or scales. The most common instrument in use is the Cochrane technique, which assesses biases in the methodologies, results, conclusions, and other sections of SRsby using judgments of low risks, unclear risks, and high risks on various axes (Cote et al. 2016, p. 533). This SR utilized the Cochrane approach to assessing the inclination hazard in the various reports that were incorporated into the SR.

\section{Results:- \\ Summary}

As evident in the PRISMA chart, the first results obtained in the review were from the literature search. Searching the literature from different databases resulted in identifying and retrieving thirty articles. The reference pages of those thirty publications were utilized to get other seven sources. Therefore, the total number of reports acquired from the exploration of the databases already mentioned earlier was thirty-seven. The thirty-seven articles were exposed to different checks to empower the identification and determination of those that could be used in the review as sources. Their titles and abstracts were checked, and twelve duplicates were pinpointed, which were removed. In this regard, only twenty-five articles remained and were subjected to the other checks.

For instance, the twenty-five publications were screened. During the screening, the abstracts and titles of the twentyfive reports were assessed to decide their qualification to be incorporated into the SR. Ten of the reports failed to meet the qualification standards; hence, they were omitted from the SR.Only fifteen articles remained after this second check. The fifteen publications were subjected to the last check, which was a full-content evaluation. It excluded only fivereports that did not meet the eligibility criteria. Ultimately, only tenpublications were encompassed in the review because they met the inclusion criterion.

\section{Characteristics of the Studies}

The features of the studies of interest were authors, years of publication, design, and outcomes. There was more than one author who undertook the reportsincorporated into the review and published their methodologies and results. Therefore, when considering this characteristic, more than one author wrote $100 \%$ of the reports that were used in the SR as sources. Those particular reports were published in different years. For instance, 10\%, 30\%, 30\%, and 30\% of the articles were published in 2016, 2017, 2018, and 2019, respectively. As for the designs of the studies, the majority of them used the experimental technique, representing $90 \%$ of the publications incorporated into the SR. The other $10 \%$ of the articles were systematic reviews. This information is illustrated in Appendix A.The last feature of the studies was their outcomes. This section is discussed in detail in the subsequent section of the review.

Apart from the four main characteristics mentioned above, each of the reports included in the SR presented a specific level of bias as can be seen in Appendix B. From the table in Appendix B;three variables were utilized to evaluate the quality of the publications: low risk, high risk, and unclear risk. Precise symbols were employed to 
denote each of the three variables. Low risk was denoted by (+), high risk by (-), and unclear risk by (?). As evident in Appendix B, these variables were assigned to each report based on seven distinct measures. The outcomes suggest that all the articles included in the review have a low reporting bias risk and high-performance bias risk. When considering the other measures of the Cochrane method, the reports illuminated low bias risk. Therefore, the publications' quality warranted their inclusion in the review.

\section{Outcomes of the Studies}

This review found out compelling facts regarding the antimicrobial activities of several endodontic sealers. Numerous scholars and researchers have focused their studies on how different endodontic sealers inhibit the growth of distinct oral bacteria and their ability to cause disease. For instance, Dalmia et al. (2018, p. 104), Gurel, Demiryurek, Ozyurek, and Gulhan(2016, p. 19), Huang et al. (2019, p. 118), Kapralos, Koutroulis,Ørstavik, Sunde, and Rukke(2018, p. 149), and Loyola-Rodríguez et al. (2019, p. 1) focused their studies on assessing the antimicrobial effects of MTA Fillapex, Tubliseal, AH Plus, Sealapex, Smartpaste Bio, ProRoot MTA, and Totalfill $\mathrm{BC}$ against specific bacteria like $C$. albicans, E. faecalis, E. coli, P. aeruginosa, and $S$. aureus. Each of these groups of scholars discovered exciting facts concerning the antimicrobial features of the sealers already mentioned.

A good number of the researchers acknowledge that a significant number of these endodontic sealers possess antimicrobial activity. Dalmia et al. (2018, p. 104) posit that in ascending order, MTA Fillapex, Tubliseal, AH Plus, and Sealapex, these endodontic sealers show some microorganism growth inhibition of $E$. faecalis. This finding suggests that all these four endodontic sealers have antimicrobial activity, though with varying effectiveness. Gurel et al. (2016, p. 19) agree with this sentiment by explaining that in agar diffusion test (ADT), AH Plus, MTA Fillapex, and Smartpaste Bio have antimicrobial effects on microorganisms, such as $S$. aureus, C. albicans,E. coli,P. aeruginosa, and E. faecalis.As for direct contact test (DCT), AH Plus, ProRoot MTA, and RealSeal have potent antimicrobial effects against $C$. albicans, E. coli, and E. faecalis (Huang et al. 2019, p. 118). However, Huang et al. (2019, p. 118) outline that the bactericidal potential of AH Plus diminishes significantly with time. Similarly, the authors explain that in the agar diffusion test (ADT), RealSeal, ProRoot MTA, andAH Plus present inhibition regions against allthree microorganisms already highlighted. In both DCT and ADT, Guttaflow2 has no bactericidal effects against the three microorganisms (Huang et al. 2019, p. 118). In this regard, this finding finds one endodontic sealer without antimicrobial activity against oral bacteria, which is Guttaflow2.

The other two groups of scholars and researchers decided to evaluate the antibacterial activityand effectiveness of sealers in bacterial biofilms and when they are combined with specific nanoparticles.Kapralos et al. (2018, p. 149) highlight that in bacterial biofilms, AH Plus shows higher antimicrobial effectiveness than Totalfill BC sealer through the first twenty-four hours followingsetting.Loyola-Rodríguez et al. $(2019$, p. 1) deviate a bit from this focus and explain that when combined with nanoparticles like chitosan (CsNPs) and a chlorhexidine (Chx) CsNPsChx, AH Plus and Tubliseal can control E. faecalis during endodontic treatments. Even though these findings provide both antimicrobial activity and effectiveness of several kinds of endodontic sealers, other scholars like Monajemzadeh, Asoor, Aslani, and Sadeghi-Nejad(2017, p. 7), Munitić, Peričić, Utrobičić, Bago, and Puljak (2019, p. 1), Poggio, Trovati, Ceci, Colombo, and Pietrocola (2017, p. 743), Shin, Lee, and Lee (2018, p. 54), and Tandon et al. (2017, p. 98)also assessed some of those endodontic sealers and their inhibition property.They also provide similar results to the ones already highlighted by the other group of scholars.

Instead of focusing only on the antibacterialactivity of various sealers against numerous types of microorganisms, this second group of researchers also extended their scope of research to include the inhibition and effectiveness of those particular sealers. Monajemzadeh et al. (2017, p. 7)highlight that the descending sequence of bacteria growth inhibition or antimicrobial effectiveness against microorganisms like Lactobacillus casei, Streptococcus mutans, Streptococcus salivarius, Streptococcus sanguis, and Candida albicansis as follows:MTA, zinc oxide eugenol (ZOE), and resin ( $\mathrm{AH} 26)$. This finding is in line with another that posits that bioceramics sealers possess various degrees of antibacterial activity (Munitić et al. 2019, p. 1). Similarly, Poggio et al. (2017, p. 743) point out that apart from TotalFill BC Sealer, all the other types of endodontic sealers showed antimicrobial activity against Enterococcus faecaliswhen using ADT.N2 and EasySeal sealers manifested the highest antibacterial effect on the microorganism, followed by AH plus sealers and Pulp Canal Sealers, with Sealapex Root Canal Sealer, MTA Fillapex, and BioRoot ${ }^{\mathrm{TM}} \mathrm{RCS}$ having the lowest antimicrobial impact on the bacteria.Using the direct contact test (DCT), both EasySeal and TotalFill BC Sealers were bactericidal against the microorganism and killed it. The other sealers already mentioned were also bactericidal against the bacteria at specific contact times (Poggio et al. 2017, p. 743). These findings extend the broad scope of antimicrobial properties of the endodontic sealers already mentioned. 
From the information underscored above, it seems that several scholars and researchers agree with the antimicrobial properties of a significant number of endodontic sealers. Shin et al. (2018, p. 54) and Tandon et al. (2017, p. 98) also share similar findings. Shin et al. (2018, p. 54) posit that Tubli-Seal, Sealapex, and AH Plus have intense antimicrobial activity against bacteria such as $P$. endodontalisand $P$. gingivalis, which are Gram-negative. Endosealsealers possess strong bactericidal properties against the two Gram-negative bacteria as well as E. faecalis, which is a Gram-positive bacterium. Endosequence BC seal manifests weak bactericidal effect against all the three microorganisms already mentioned (Shin et al. 2018, p. 54).Tandon et al. (2017, p. 98) then go ahead to claim that in descending order, Zinc Oxide Eugenol sealer, AH Plus, Roekoseal, and Sealapex, these endodontic sealers manifest antibacterial activity on E. faecalis.Therefore, existing literature has provided the effectiveness, antimicrobial activity, and inhibition potential of different types of endodontic sealers against various kinds of oral bacteria.

\section{Conclusion:-}

The reports included in this review were essential in ensuring the paper's objective was met. All the articles focused on highlighting the antibacterial properties of several types of sealers. From theirfindings, it is apparent that various types of endodontic sealers possess antimicrobial activity against numerous oral bacteria. However, it should be noted that the level and effectiveness of their bactericidal effect differ. Some sealers function better and are more effective than others against specific bacteria than others. Therefore, more research should be undertaken to determine the antimicrobial properties and effectiveness of specific endodontic sealers against precise oral bacteria to enable a proper comparative analysis.

\section{References:-}

1. Al-Haddad, A., Ab Aziz, C. and Zeti, A.(2016)'Bioceramic-based root canal sealers: A review',International Journal of Biomaterials, 2016, pp. 1-10. DOI: http://dx.doi.org/10.1155/2016/9753210.

2. Ali, Z. and Bhaskar, S.B. (2016) 'Basic statistical tools in research and data analysis', Indian Journal of Anaesthesia, 60(9), pp.662-669. DOI: 10.4103/0019-5049.190623.

3. Baumann, N. (2016) 'How to use the medical subject headings (MeSH)', International Journal of Clinical Practice, 70(2), pp.171-174. DOI: 10.1111/ijcp.12767.

4. Cote, M.P., Apostolakos, J.M., Voss, A., DiVenere, J., Arciero, R.A. and Mazzocca, A.D. (2016) 'A systematic review of meta-analyses published in Arthroscopy: The Journal of Arthroscopic and Related Surgery', Arthroscopy: The Journal of Arthroscopic \& Related Surgery, 32(3), pp.528-537. DOI: 10.1016/j.arthro.2015.08.002.

5. Dalmia, S., Gaikwad, A., Samuel, R., Aher, G., Gulve, M. and Kolhe, S., (2018)'Antimicrobial efficacy of different endodontic sealers against Enterococcus faecalis: An In vitro study',Journal of International Society of Preventive \& Community Dentistry, 8(2), pp.104-109.DOI: 10.4103/jispcd.JISPCD_29_18.

6. Dijkers, M. (2017) 'How good is that systematic review?', KT Update, 5(5), pp.1-9, viewed $31^{\text {st }}$ October 2018, 〈http://ktdrr.org/products/update/v5n5/dijkers_ktupdate_v5n5-508.pdf>.

7. Gholamhoseini, Z., Alizadeh, S.A. and Bolbolian, M., (2018)'In vitro evaluation of antimicrobial activity of three bioceramic endodontic sealers on Enterococcus Faecalis and Staphylococcus Aureus',Annals of Dental Specialty, 6(3), pp.261-263. $\quad$ Retrieved from https://annalsofdentalspecialty.net.in/storage/models/article/z7QyWL0H8zAqHycxzphBsOtRQKthyca4mu5RV TPgKli1743PS5liXO31YA6a/in-vitro-evaluation-of-antimicrobial-activity-of-three-bioceramic-endodonticsealers-against-enter.pdf.

8. Gurel, M., Demiryurek, E., Ozyurek, T. and Gulhan, T., (2016) Antimicrobial activities of different bioceramic root canal sealers on various bacterial species',International Journal of Applied Dental Sciences, 2(3), pp.19-22. Available at $\langle\mathrm{http}: / / \mathrm{www}$.oraljournal.com/vol2issue3/pdf/2-2-32.1.pdf $>$.

9. Huang, Y., Li, X., Mandal, P., Wu, Y., Liu, L., Gui, H. and Liu, J., (2019)'The in vitro antimicrobial activities of four endodontic sealers',BMC Oral Health, 19(1), p.118. DOI: https://doi.org/10.1186/s12903-019-0817-2.

10. Jahan, N., Naveed, S., Zeshan, M. and Tahir, M.A. (2016) 'How to conduct a systematic review: a narrative literature review', Cureus, 8(11), e864. DOI: 10.7759/cureus.864.

11. Kapralos, V., Koutroulis, A., Ørstavik, D., Sunde, P.T. and Rukke, H.V., (2018)'Antibacterial activity of endodontic sealers against planktonic bacteria and bacteria in biofilms',Journal of Endodontics, 44(1), pp.149154. DOI: https://doi.org/10.1016/j.joen.2017.08.023.

12. Loyola-Rodríguez, J.P., Torres-Méndez, F., Espinosa-Cristobal, L.F., García-Cortes, J.O., Loyola-Leyva, A., González, F.J., Soto-Barreras, U., Nieto-Aguilar, R. and Contreras-Palma, G., (2019)'Antimicrobial activity of endodontic sealers and medications containing chitosan and silver nanoparticles against Enterococcus 
faecalis',Journal of Applied Biomaterials \& Functional Materials, 17(3), pp. 1-9. DOI: 10.1177/2280800019851771.

13. Monajemzadeh, A., Asoor, S.A., Aslani, S. and Sadeghi-Nejad, B., (2017)'In vitro antimicrobial effect of different root canal sealers against oral pathogens',Current Medical Mycology, 3(2), pp. 7-12. DOI: 10.29252/cmm.3.2.7.

14. Munitić, M.Š., Peričić, T.P., Utrobičić, A., Bago, I. and Puljak, L., (2019)‘Antimicrobial efficacy of commercially available endodontic bioceramic root canal sealers: A systematic review',PloS One, 14(10), pp. 1-20. DOI: https://doi.org/10.1371/journal.pone.0223575.

15. Page, M.J., McKenzie, J.E. and Higgins, J.P. (2018) 'Tools for assessing risk of reporting biases in studies and syntheses of studies: a systematic review', BMJ Open, 8(3), p.e019703. DOI: 10.1136/bmjopen-2017-019703.

16. Page, M.J., Shamseer, L. and Tricco, A.C. (2018) 'Registration of systematic reviews in PROSPERO: 30,000 records and counting', Systematic Reviews, 7(1), p.32. DOI: https://doi.org/10.1186/s13643-018-0699-4.

17. Poggio, C., Trovati, F., Ceci, M., Colombo, M. and Pietrocola, G., (2017)'Antibacterial activity of different root canal sealers against Enterococcus faecalis',Journal of Clinical and Experimental Dentistry, 9(6), p.e743e748.DOI:10.4317/jced.53753.

18. Pussegoda, K., Turner, L., Garritty, C., Mayhew, A., Skidmore, B., Stevens, A., Boutron, I., Sarkis-Onofre, R., Bjerre, L.M., Hróbjartsson, A. and Altman, D.G. (2017) 'Systematic review adherence to methodological or reporting quality', Systematic Reviews, 6(1), p.131. DOI: 10.1186/s13643-017-0527-2.

19. Selçuk, A.A., (2019)'A Guide for Systematic Reviews: PRISMA',Turkish Archives of Otorhinolaryngology, 57(1), pp.57-58.DOI: 10.5152/tao.2019.4058.

20. Shin, J.H., Lee, D.Y. and Lee, S.H., (2018) Comparison of antimicrobial activity of traditional and new developed root sealers against pathogens related root canal',Journal of Dental Sciences, 13(1), pp.54-59.DOI: https://doi.org/10.1016/j.jds.2017.10.007.

21. Tandon, B., Uppin, V.M., Hogade, S.A., Chaudhry, S., Bansal, S. and Bansal, S.(2017)'Antibacterial activity of four root canal sealers against Enterococcus Faecalis at 1st, 3rd, 5th, and 7th day duration: A In vitro study',Indian Journal of Dental Sciences, 9(2), pp. 98-104. DOI:10.4103/IJDS.IJDS_22_17.

Appendices:-

Appendix A

Characteristics of the Studies

\begin{tabular}{|c|c|c|c|}
\hline Author(s) & $\begin{array}{l}\text { Publication } \\
\text { Year }\end{array}$ & Study Design & Outcome(s) \\
\hline $\begin{array}{lr}\text { Dalmia, } & \text { S., } \\
\text { Gaikwad, } & \text { A., } \\
\text { Samuel, R., Aher, } \\
\text { G.,Gulve, M. and } \\
\text { Kolhe, S. }\end{array}$ & 2018 & Experimental & $\begin{array}{l}\text { In ascending order, MTA Fillapex, Tubliseal, AH } \\
\text { Plus, and Sealapex, these endodontic sealers show } \\
\text { some microorganism growth inhibition of } E \text {. } \\
\text { faecalis. }\end{array}$ \\
\hline $\begin{array}{lr}\text { Gurel, } & \text { M., } \\
\text { Demiryurek, } & \text { E., } \\
\text { Ozyurek, T. } & \text { and } \\
\text { Gulhan, T. } & \end{array}$ & 2016 & Experimental & $\begin{array}{l}\text { In agar diffusion test (ADT), AH Plus, MTA } \\
\text { Fillapex, and Smartpaste Bio have antimicrobial } \\
\text { effects on microorganisms, such as E. coli, C. } \\
\text { albicans, } P \text {. aeruginosa, S. aureus, and E. faecalis. }\end{array}$ \\
\hline $\begin{array}{l}\text { Huang, Y., Li, X., } \\
\text { Mandal, P., Wu, Y., } \\
\text { Liu, L., Gui, H. and } \\
\text { Liu, J. }\end{array}$ & 2019 & Experimental & $\begin{array}{l}\text { In direct contact test (DCT), AH Plus, ProRoot } \\
\text { MTA, and RealSealhave potent antimicrobial } \\
\text { effects against } C \text {. albicans, E. coli, and E. } \\
\text { faecalis. However, the bactericidal potential of AH } \\
\text { Plus diminishes significantly with time. In agar } \\
\text { diffusion test (ADT), RealSeal, AH Plus, and } \\
\text { ProRootMTApresentinhibition zones against all } \\
\text { three microorganisms. In both ADT and DCT, } \\
\text { Guttaflow2 has no bactericidal effects against the } \\
\text { three microorganisms. }\end{array}$ \\
\hline $\begin{array}{lr}\text { Kapralos, } & \text { V., } \\
\text { Koutroulis, } & \text { A., } \\
\text { Ørstavik, D., Sunde, } \\
\text { P.T. and Rukke, } \\
\text { H.V. }\end{array}$ & 2018 & Experimental & $\begin{array}{l}\text { In bacterial biofilms, AH Plus shows higher } \\
\text { antimicrobial effectiveness than Totalfill BC sealer } \\
\text { during the first twenty-four hours after setting. }\end{array}$ \\
\hline
\end{tabular}




\begin{tabular}{|c|c|c|c|}
\hline $\begin{array}{l}\text { Loyola-Rodríguez, } \\
\text { J.P., Torres-Méndez, } \\
\text { F., Espinosa- } \\
\text { Cristobal, } \quad \text { L.F., } \\
\text { García-Cortes, J.O., } \\
\text { Loyola-Leyva, A., } \\
\text { González, F.J., Soto- } \\
\text { Barreras, U., Nieto- } \\
\text { Aguilar, R. and } \\
\text { Contreras-Palma, G. }\end{array}$ & 2019 & Experimental & $\begin{array}{l}\text { When combined with nanoparticles like chitosan } \\
\text { (CsNPs) and chlorhexidine (Chx)CsNPs-Chx,AH } \\
\text { Plus and Tublisealcan control E. faecalisduring } \\
\text { endodontic treatments. }\end{array}$ \\
\hline $\begin{array}{l}\text { Monajemzadeh, A., } \\
\text { Asoor, S.A., Aslani, } \\
\text { S. and Sadeghi- } \\
\text { Nejad, B. }\end{array}$ & 2017 & Experimental & $\begin{array}{l}\text { The descending sequence of bacteria growth } \\
\text { inhibition or antimicrobial effectiveness against } \\
\text { microorganisms like Lactobacillus casei, } \\
\text { Streptococcus mutans, Streptococcus } \\
\text { salivarius,Streptococcussanguis, and Candida } \\
\text { albicansis as follows: mineral trioxide aggregate } \\
\text { (MTA),zinc oxide eugenol (ZOE), and resin (AH } \\
\text { 26). }\end{array}$ \\
\hline $\begin{array}{lr}\text { Munitić, } & \text { M.Š., } \\
\text { Peričić, } & \text { T.P., } \\
\text { Utrobičić, A.,Bago, } \\
\text { I. and Puljak, L. }\end{array}$ & 2019 & Systematic review & $\begin{array}{l}\text { Bioceramics sealers possessvarious degrees of } \\
\text { antibacterial activity. }\end{array}$ \\
\hline $\begin{array}{l}\text { Poggio, C., Trovati, } \\
\text { F., Ceci, } \quad \text { M., } \\
\text { Colombo, M. and } \\
\text { Pietrocola, G. }\end{array}$ & 2017 & Experimental & $\begin{array}{l}\text { Apart from TotalFill BC Sealer, all the other types } \\
\text { of endodontic sealers showed antibacterial } \\
\text { activityagainstEnterococcus faecaliswhen using } \\
\text { agar diffusion test (ADT). N2 and EasySeal sealers } \\
\text { manifested the highest antibacterial effect on the } \\
\text { microorganism, followed by AH plus sealers and } \\
\text { Pulp Canal Sealers, with Sealapex Root Canal } \\
\text { Sealer, MTA Fillapex, and BioRoot }{ }^{\mathrm{TM}} \text { RCS having } \\
\text { the lowest antimicrobial impact on the } \\
\text { bacteria.Using the direct contact test (DCT), both } \\
\text { EasySeal and TotalFill BC Sealers were } \\
\text { bactericidal against the microorganism and killed } \\
\text { it. The other sealers already mentioned were also } \\
\text { bactericidal against the bacteria at specific contact } \\
\text { times. }\end{array}$ \\
\hline $\begin{array}{l}\text { Shin, J.H., Lee, D.Y. } \\
\text { and Lee, S.H. }\end{array}$ & 2018 & Experimental & $\begin{array}{l}\text { Tubli-Seal, Sealapex, and } \mathrm{AH} \text { Plus have potent } \\
\text { antimicrobial activity against bacteria such as } P \text {. } \\
\text { gingivalisand } P \text {. endodontalis, which are Gram- } \\
\text { negative. Endosealsealers have strong bactericidal } \\
\text { properties against the two Gram-negative bacteria } \\
\text { as well as E. faecalis, which is a Gram-positive } \\
\text { bacterium. Endosequence BC seal manifests weak } \\
\text { bactericidal effect against all the three } \\
\text { microorganisms already mentioned. }\end{array}$ \\
\hline $\begin{array}{l}\text { Tandon, B., Uppin, } \\
\text { V.M., Hogade, S.A., } \\
\text { Chaudhry, } r \text { S., } \\
\begin{array}{ll}\text { Bansal, } \quad \text { S. and } \\
\text { Bansal, S. }\end{array}\end{array}$ & 2017 & Experimental & $\begin{array}{l}\text { In descending order, Zinc Oxide Eugenol sealer, } \\
\text { AH Plus, Roekoseal, and Sealapex, these } \\
\text { endodontic sealers manifest antibacterial activity } \\
\text { on E. faecalis. }\end{array}$ \\
\hline
\end{tabular}

Appendix B:

Cochrane Bias Risk Assessment

\begin{tabular}{|l|l|l|l|l|l|l|l|}
\hline Study & Selection & Selection Bias & Performance & Detention & Attrition & Reporting & Other \\
\hline
\end{tabular}




\begin{tabular}{|c|c|c|c|c|c|c|c|}
\hline & $\begin{array}{l}\text { Bias } \\
\text { (Random } \\
\text { Sequence } \\
\text { Generation) }\end{array}$ & $\begin{array}{l}\text { (Allocation } \\
\text { Concealment) }\end{array}$ & Bias & Bias & Bias & Bias & Bias \\
\hline $\begin{array}{lr}\text { Dalmia, } & \text { S., } \\
\text { Gaikwad, } & \text { A., } \\
\text { Samuel, } & \text { R., } \\
\text { Aher, G.,Gulve, } \\
\text { M. and Kolhe, S. }\end{array}$ & + & + & - & - & $?$ & + & + \\
\hline $\begin{array}{l}\text { Gurel, } \\
\text { Demiryurek, E., } \\
\text { Ozyurek, T. and } \\
\text { Gulhan, T. }\end{array}$ & + & + & - & + & + & + & $?$ \\
\hline $\begin{array}{l}\text { Huang, Y., Li, } \\
\text { X., Mandal, P., } \\
\text { Wu, Y., Liu, L., } \\
\text { Gui, H. and Liu, } \\
\text { J. }\end{array}$ & + & + & - & - & + & + & ? \\
\hline $\begin{array}{lr}\text { Kapralos, } & \text { V., } \\
\text { Koutroulis, } & \text { A., } \\
\text { Ørstavik, } & \text { D., } \\
\text { Sunde, P.T. } & \text { and } \\
\text { Rukke, H.V. } & \end{array}$ & + & + & - & + & + & + & + \\
\hline 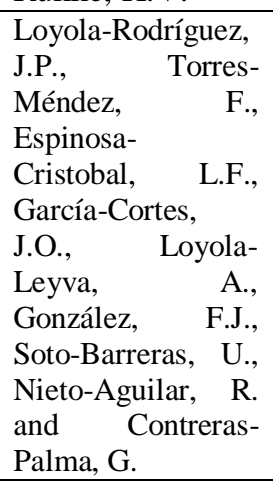 & + & + & - & + & + & + & $?$ \\
\hline $\begin{array}{l}\text { Monajemzadeh, } \\
\text { A., Asoor, S.A., } \\
\text { Aslani, S. and } \\
\text { Sadeghi-Nejad, B. }\end{array}$ & + & + & - & - & $?$ & + & + \\
\hline $\begin{array}{lr}\begin{array}{l}\text { Munitić, } \\
\text { Peričić, }\end{array} & \text { M.Š., } \\
\text { Utrobičić, } & \\
\begin{array}{l}\text { A.,Bago, } \\
\text { Puljak, L. }\end{array} & \\
\end{array}$ & + & + & - & + & + & + & $?$ \\
\hline $\begin{array}{l}\text { Poggio, } \quad \text { C., } \\
\text { Trovati, F., Ceci, } \\
\text { M., Colombo, M. } \\
\text { and Pietrocola, G. }\end{array}$ & + & + & - & - & + & + & $?$ \\
\hline $\begin{array}{l}\text { Shin, J.H.,Lee, } \\
\text { D.Y. and Lee, S.H. }\end{array}$ & + & + & - & + & + & + & + \\
\hline $\begin{array}{l}\text { Tandon, B., Uppin, } \\
\text { V.M., Hogade, } \\
\text { S.A., Chaudhry, S., } \\
\text { Bansal, S. and } \\
\text { Bansal, S. }\end{array}$ & + & + & - & + & + & + & $?$ \\
\hline
\end{tabular}

